\title{
Finnish nurses' views of support provided to families about traumatic brain injury patients' daily activities and care
}

\author{
Kirsi Coco ${ }^{1}$, Kerttu Tossavainen ${ }^{1}$, J uha E. J ääskeläinen ${ }^{2}$, Hannele Turunen ${ }^{1,2}$ \\ 1. Department of Nursing Science, University of Eastern Finland, Kuopio Campus, Finland. 2. Kuopio University Hospital, \\ Finland.
}

Correspondence: Kirsi Coco. Address: Department of Nursing Science, University of Eastern Finland, Kuopio Campus, Finland. Telephone: 35-840-821-5057. Email: kirsi.coco@gmail.com.

Received: May 31, 2012

DOI : $10.5430 /$ jnep.v3n3p112
Accepted: September 5, 2012 Online Published: November 22, 2012

URL: http://dx.doi.org/10.5430/jnep.v3n3p112

\section{Abstract}

Background: Large numbers, almost eight million, of brain injuries are diagnosed worldwide annually. Social support (informational, emotional and practical) has been identified as essential for helping members of TBI patients' families to cope with the severe situations these injuries cause. We have assessed nurses' views of the support provided in Finland.

Methods: The target group included all nursing staff $(n=172)$ of neurosurgical wards in Finland. Data were collected during 2010, from 115 of these nurses working in neurosurgical wards of all five Finnish university hospitals. The response rate was $67 \%$. The data were analysed (using SPSS version 17 software) by calculating descriptive statistics, applying Kolmogorov-Smirnov tests, and ANOVA (one- and two-way), MANOVA and linear regression analyses.

Results: The results indicate that nurses' education affects the practical support they provide to TBI patients' family members: registered nurses considered themselves most likely to take into account issues related to liaison with family members. The length of work experience was related to how often nurses reported discussing mood swings and other TBI symptoms with family members.

Conclusions: Providing practical support to TBI patients' family members requires nurses to possess multidimensional practical competences related to the symptoms caused by the brain injury.

\section{Key words}

Traumatic brain injury patient, Family member, Practical support, Nurses

\section{Introduction}

Every year, nearly eight million traumatic brain injuries (TBIs) are diagnosed globally ${ }^{[1]}$. The main causes of TBIs treated in hospitals are traffic accidents, fall-related TBIs, violence ${ }^{[2-4]}$ and exposure to blasts, among military personnel on active duty in war zones ${ }^{[5]}$. Nursing staff on neurosurgical wards need extensive competency when caring for TBI patients and dealing with their family members. The latter is important because fostering the involvement of families and their ability to cope improves their well-being and can promote the TBI patient's ability to cope ${ }^{[6-8]}$. According to a recently published model, providers of patient- and family-centered care should foster dignity and respect by listening to and honoring 
families' perspectives and choices. In addition, they should empower them by sharing timely, accurate and complete information, and collaboratively supporting families' participation in care and decision-making, at whatever level they choose $^{[9]}$.

Patients and their families need practical support during both their hospital care and the recovery process. The diverse symptoms often associated with TBI include physical and behavioral dysfunctions. Thus, TBI patients' family members need practical support from nursing staff to learn how to help the patients with daily activities and ways to deal with problematic situations ${ }^{[10,11]}$. For instance, TBI patients may not understand their limitations, as they are not aware of their symptoms ${ }^{[12-14]}$. Family members need support and teaching during the acute phase in order to be able to care for the patients when they return home ${ }^{[15]}$. However, family members have reported that they receive insufficient support in relation to patients' behavioral dysfunctions and mood swings ${ }^{[14-17]}$.

Rehabilitation after a brain injury begins as soon as the TBI patient's condition allows it ${ }^{[2,3,11]}$. Family members need support during the early phase with respect to the provision of available services, which need to be delivered flexibly. However, family members are often unclear about the support services they could receive, so they need help in obtaining them. Family members consider that professionals do not know about the support services available and that it is important to have appropriate aids at home ${ }^{[18]}$. Thus, opportunities to discuss appropriate aids with an occupational therapist or physiotherapist, for example, are helpful for them ${ }^{[19]}$. Previous studies have also found that liaison with a social worker ${ }^{[20,21]}$ and chances to take a break from caring for the patient enhance the wellbeing of TBI patients' family members ${ }^{[14,16,22]}$.

Family members report that their know-how is not sufficiently taken into account, which leads to health care professionals drawing false conclusions about the TBI patient's situation. A TBI can lead to changes in family members' working lives and their ability to earn a living as well as their time management ${ }^{[4,15]}$. Thus, some family members also express the need for advice about the financial support they may be entitled to after the patient comes home from hospital ${ }^{[3,11]}$.

Several previous studies have examined TBI patients' family members' needs and ability to cope after the injury during both the acute phase in the intensive care unit and rehabilitation ${ }^{[23-25]}$. There is also published information on nursing staff's experiences in relation to dealing with TBI patients' family members ${ }^{[26-28]}$. However, the practical support given to TBI patients' family members has been little researched from the nursing staff's perspective.

Therefore, the presented study examines the information and competence nurses believe they require when providing practical support for family members of adult TBI patients. In accordance with the model mentioned above, practical support for family members of TBI patients is defined here as supporting family members' decision-making, promoting their welfare, encouraging them to participate in care, cooperating with them, and counseling.

\section{Subjects and methods}

The main aims of this study were to examine how often nurses on neurosurgical wards perceive they provide practical support to TBI patients' family members and the level of competence needed to do this effectively. We also explored correlations between nurses' background characteristics and their perceptions of both related interventions and level of competence needed to support TBI patients' family members.

The specific research questions addressed were:

- How often do members of the nursing staff in your unit provide practical support to TBI patients' family members?

- What level of competence (basic/advanced; not defined) do members of the nursing staff consider is needed when providing practical support to TBI patients' family members? 
- What is the connection between the level of competence and the practical support offered to TBI patients' family members?

- $\quad$ Are the background characteristics of nursing staff (age, education, work experience, experience in current work unit) related to how often they provide practical support to TBI patients' family members and the level of competence required?

The results reported in this paper are from part of a wider study relating to the support given to TBI patients' family members. The data were collected using a structured self-completed questionnaire formulated for the study. The statements included were based on previous research related to the topic ${ }^{[1,2,3,7]}$, a systematic literature review ${ }^{[29]}$ and evaluations by a team of experts (two registered nurses, a practical nurse, a nurse manager, an anesthetist and a neurosurgeon). The statements were rated by respondents on a six-point scale: $5=$ always, $4=$ often, $3=$ occasionally, $2=$ seldom, $1=$ never and $0=$ does not affect me. The nurses were also asked to evaluate (based on their own perceptions) whether the issue addressed in each statement required basic or advanced competence. These responses were binominal: 1 = basic competence and 2 advanced competence. Two members of nursing staff with extensive work experience in treating TBI patients also undertook preliminary testing of the covering letter and questionnaire. Most of the statements were found to be understandable and the alternatives clear. However, some modifications were made to the questionnaire based on this pre-testing and the views of the team of experts.

\subsection{Sample and data collection}

The target group was all nursing staff ( $\mathrm{N}=172)$ on neurosurgical wards of all five Finnish university hospitals, six wards in total. This group included all registered nurses and practical nurses, together with assistant head nurses and head nurses; all of who were invited to participate in the study. The questionnaires were sent to contacts according to the protocols of each employer, who then forwarded them to the participants. The participants returned the questionnaires directly to the researcher in an envelope with prepaid postage. The data collection started in April and finished in July 2010; in total 115 nursing staff members returned the questionnaire. The response rate was $67 \%$.

\subsection{Data processing}

The data were statistically analyzed using SPSS version 17 software. Descriptive statistics [frequencies, means, standard deviations (SD)] were calculated and examined first. For further analyses the age groups and education were reclassified. Factor analysis was carried out using the principal axis factoring method with Varimax rotation, and an eigenvalue greater than one. All responses to statements of " $0=$ does not affect me" were excluded from the factor analyses. Communality describes the suitability of a variable in a factor solution; its value should exceed $0.3^{[30]}$. This was the case in the current study, in which communalities varied between 0.304 and 0.793 . A five factor solution explained $59.7 \%$ of the total variance in the answers about the practical support of brain injury patients' family members. The levels of variance differed between these five factors as follows: Teaching family members in daily activities (F1) 38.8 \%; Teaching family members to deal with the patient's mood swings and symptoms caused by TBI (F2) $7.0 \%$; Supporting family members by providing breaks and recreation (F3) $6.7 \%$; Planning the TBI patient's discharge from hospital (F4) 4.0\%; and Liaison with family members (F5) $3.1 \%$.

Based on the factors, five sum variables describing interventions associated with practical support were constructed and the Kolmogorov-Smirnov test indicated that their distributions were normal. The mean value for the nursing intervention sum variables ranged from 1 (never) to 5 (always). The means, highest and lowest values and Cronbach's alpha coefficients were calculated from the nursing intervention sum variables (see Table 2). The nursing intervention sum variables were also examined along with the background variables by analyzing their relationships to how the nursing staff evaluated the practical support they provide to family members on neurosurgical wards. In addition, the relationships and interactions between background variables and the intervention sum variables were examined using One-way ANOVA, Two-way ANOVA and MANOVA. Linear regression was used to investigate the relationships between the background characteristics and nursing staff's evaluations of how often they provided practical support to brain injury patients' family 
members. We also examined whether there were significant differences between or among background characteristics (age, education, work experience as a nursing staff member, work experience in current work unit as a nursing staff member) and how often nurses provided practical support to the TBI patients' family members.

Next, the respondents' assessments of whether basic or advanced competence was needed to support TBI patients' family members was examined, using data from the nurses $(n=66)$ who provided relevant evaluations. Percentage distributions were used to describe nursing staff's classifications of the statements regarding practical support for TBI patients' family members with respect to required level of competence. The level of competence required was considered to be that which received more than $50 \%$ of the classifications in the nurses' responses.

Finally, five competence sum variables were formulated based on the structure of the nursing intervention sum variables (teaching family members in daily activities, teaching family members to deal with the patient's mood swings and the symptoms caused by TBI, supporting family members by providing breaks and recreation, planning the TBI patient's discharge from hospital, liaison with family members). The mean values for the competence sum variables ranged from 1 (basic competence) to 2 (advanced competence). The statistical significance of differences between means was tested by the Bonferroni test. Correlation coefficients (calculated using linear regression analysis, two-way ANOVA and MANOVA) were used to investigate the correlations and interactions between the background characteristics and competence sum variables.

In the following sections only statistically significant $(p<0.05)$ results are presented. The internal consistency of the sum variables was assessed using Cronbach's alpha coefficient ${ }^{[30]}$.

\section{Results}

\subsection{Participants}

Most (84 \%) of the participants were registered nurses the remainders were practical nurses. The ages of the participants ranged from 21 to 62 years, the mean age was 40 years and $97 \%$ were women. Of the respondents, $60 \%$ had been working on their current neurosurgical ward for 10 years or less (see Table 1).

Table 1. Nursing staff: background information $(\mathrm{n}=115)$

\begin{tabular}{|c|c|c|c|}
\hline \multicolumn{2}{|c|}{ Background characteristics } & \multirow{2}{*}{$\begin{array}{l}\mathbf{n} \\
109\end{array}$} & \multirow{2}{*}{$\begin{array}{c}\text { \% } \\
97\end{array}$} \\
\hline Gender $(\mathrm{n}=113)$ & Female & & \\
\hline & Male & 4 & 3 \\
\hline \multirow[t]{3}{*}{$\begin{array}{l}\text { Age group (years) } \\
(\mathrm{n}=114)\end{array}$} & Under 35 & 39 & 34 \\
\hline & $36-45$ years & 35 & 30 \\
\hline & 46 years or more & 38 & 33 \\
\hline \multicolumn{4}{|l|}{ Education $(n=114)$} \\
\hline & Practical nurse & 18 & 16 \\
\hline & Registered nurse educated at a college of nursing & 51 & 45 \\
\hline & Registered nurse educated at a university of applied sciences & 45 & 39 \\
\hline \multicolumn{4}{|c|}{ Work experience as a nursing staff member (years) } \\
\hline \multirow[t]{4}{*}{$(\mathrm{n}=115)$} & Less than 3 years & 11 & 10 \\
\hline & 3- 10 years & 34 & 29 \\
\hline & 11- 20 years & 36 & 31 \\
\hline & 21 years or more & 34 & 30 \\
\hline \multicolumn{4}{|c|}{ Work experience as a nursing staff member in current work unit (years) } \\
\hline \multirow[t]{4}{*}{$(n=115)$} & Less than 3 years & 25 & 22 \\
\hline & 3- 10 years & 44 & 38 \\
\hline & 11- 20 years & 24 & 21 \\
\hline & 21 years or more & 22 & 19 \\
\hline
\end{tabular}


Liaison with family members. Half of the nursing staff always arranged for the family members to have a chance to speak with the attending doctor. Almost half of the nursing staff often arranged flexible visiting hours (46 \%) and a third always called family members about changes in the TBI patient's condition.

Planning the TBI patient's discharge from hospital. Two thirds of the nursing staff often informed family members about support services (e.g. the availability of a physiotherapist, speech therapist or social worker). However, only about a third of the nursing staff often included family members in planning the patient's return home from hospital and coordinated the return home in consultation with family members.

Teaching family members in daily activities. Half of the nursing staff stated that they often taught family members about how to support the TBI patient's independent functioning and how to teach the patients to take care of themselves, e.g. to eat independently. Nearly half of the nurses often taught family members how to deal with patients' swallowing difficulties or their movements when they had balance problems. Nursing staff often discussed with family members how the symptoms affected the TBI patient's ability to cope with daily activities. Family members were occasionally taught how to assist the TBI patients with eating when they had problems carrying out such activities (other than swallowing difficulties). The nursing staff occasionally taught family members about using aids and helping the TBI patients with dressing when they suffered from a lack of initiative. In addition, the nursing staff occasionally provided guidance to family members with respect to helping the patients with bathing when they suffered from poor concentration (see Table 2).

Supporting family members by providing breaks and recreation. Half of the nursing staff often supported family members by encouraging them to think about themselves. However, only a third often offered family members the chance to have a break (e.g. visiting the cafeteria or going outside), the opportunity to eat at the hospital or help with sleeping arrangements. A third of the nursing staff reported that they seldom arranged for family members to have the opportunity to rest (see Table 2).

Teaching family members in dealing with the TBI patient's mood swings and other symptoms caused by the TBI. Slightly more than half of the nursing staff stated that they often taught family members that being present and maintaining a calm environment could reduce the restlessness of a TBI patient. Forty one percent of the nursing staff occasionally taught family members about the sleep disturbances caused by TBI and a third occasionally took the TBI patient's unique situation into account when planning the patient's care. A third of the nursing staff occasionally taught family members to call an aggressive TBI patient by his or her name. Forty one percent of the nurses occasionally explained how to alleviate spasticity, and 38\% occasionally taught family members about how to anticipate and prevent aggressive behavior. Forty percent occasionally taught family members how to anticipate aggressive behavior when the patients suffered from mood swings and how to prevent aggressive behavior when the injury caused the patient to have a short temper (see Table 2).

Table 2. Practical support for the family members of TBI patients offered by nursing staff (\%, n)

\begin{tabular}{|c|c|c|c|c|c|c|c|c|}
\hline \multirow[b]{2}{*}{ Items focusing on practical support } & \multicolumn{8}{|c|}{ Nursing staff's evaluations about providing practical support \% (n) } \\
\hline & $\begin{array}{l}\text { Always } \\
\%(n)\end{array}$ & $\begin{array}{l}\text { Often } \\
\%(n)\end{array}$ & $\begin{array}{l}\text { Occasio- } \\
\text { nally } \\
\%(n)\end{array}$ & $\begin{array}{l}\text { Seldom } \\
\%(n)\end{array}$ & $\begin{array}{l}\text { Never } \\
\%(n)\end{array}$ & $\begin{array}{l}\text { Does not } \\
\text { affect me } \\
\%(n)\end{array}$ & Basic & Advanced \\
\hline \multicolumn{9}{|l|}{ Liaison with family members } \\
\hline $\begin{array}{l}\text { I arrange for TBI patients' family members to have a } \\
\text { chance to speak with the attending doctor }\end{array}$ & $51(58)$ & $43(49)$ & $3(4)$ & $2(2)$ & - & $1(1)$ & $83(54)$ & $17(11)$ \\
\hline $\begin{array}{l}\text { I arranged flexible visiting hours for TBI patients' } \\
\text { family members if needed }\end{array}$ & $33(38)$ & $46(52)$ & $17(19)$ & $2(2)$ & - & $2(3)$ & $85(55)$ & $15(10)$ \\
\hline $\begin{array}{l}\text { I call TBI patient's family members about changes in } \\
\text { the TBI patient's condition }\end{array}$ & $33(38)$ & $30(35)$ & 26(30) & $5(5)$ & $1(1)$ & $5(6)$ & $74(48)$ & 26(17) \\
\hline
\end{tabular}


Table 2. (Continued)

\begin{tabular}{|c|c|c|c|c|c|c|c|c|}
\hline \multirow[b]{2}{*}{ Items focusing on practical support } & \multicolumn{8}{|c|}{ Nursing staff's evaluations about providing practical support \% (n) } \\
\hline & $\begin{array}{l}\text { Always } \\
\%(n)\end{array}$ & $\begin{array}{l}\text { Often } \\
\%(n)\end{array}$ & $\begin{array}{l}\text { Occasio- } \\
\text { nally } \\
\%(n)\end{array}$ & $\begin{array}{l}\text { Seldom } \\
\%(n)\end{array}$ & $\begin{array}{l}\text { Never } \\
\%(n)\end{array}$ & $\begin{array}{l}\text { Does not } \\
\text { affect } \\
\text { me \%(n) }\end{array}$ & Basic & Advanced \\
\hline \multicolumn{9}{|l|}{ Planning the TBI patient's discharge from hospital } \\
\hline $\begin{array}{l}\text { I inform TBI patients' family members about support } \\
\text { services (e.g. physiotherapist, speech therapist, social } \\
\text { worker) }\end{array}$ & $13(14)$ & $61(70)$ & $19(22)$ & $6(7)$ & - & $1(1)$ & $75(48)$ & 25(16) \\
\hline $\begin{array}{l}\text { I include TBI patients' family members in planning the } \\
\text { patient's discharge from hospital }\end{array}$ & 21(23) & $37(42)$ & 23(26) & $12(14)$ & 2(2) & $5(6)$ & $71(44)$ & 29(18) \\
\hline $\begin{array}{l}\text { I coordinate a TBI patient's transfer to another care } \\
\text { unit or home in consultation with family members }\end{array}$ & $16(18)$ & $36(41)$ & $31(35)$ & $5(6)$ & 2(3) & $10(11)$ & $62(37)$ & $38(23)$ \\
\hline \multicolumn{9}{|l|}{ Teaching family members in daily activities } \\
\hline $\begin{array}{l}\text { I teach TBI patients' family members how to support } \\
\text { the patient's independent functioning }(n=114)\end{array}$ & $18(21)$ & $51(58)$ & $22(25)$ & $8(9)$ & - & 1(1) & $68(44)$ & $33(21)$ \\
\hline $\begin{array}{l}\text { I teach family members how to teach the TBI patient to } \\
\text { take care of him/herself (e.g. to eat independently }\end{array}$ & $8(9)$ & $53(61)$ & $23(26)$ & 13(15) & $1(1)$ & 2(3) & $63(42)$ & $37(25)$ \\
\hline $\begin{array}{l}\text { I teach family members with respect to eating when the } \\
\text { TBI has swallowing problems }\end{array}$ & 17(19) & 43(49) & $32(37)$ & $6(7)$ & - & 2(3) & $46(31)$ & $54(36)$ \\
\hline $\begin{array}{l}\text { I teach TBI patients' family members with moving } \\
\text { when the patient has balance problems }\end{array}$ & $15(17)$ & 43(49) & 33(37) & $7(8)$ & - & 2(3) & $48(32)$ & $52(34)$ \\
\hline $\begin{array}{l}\text { I discuss with family members the TBI patient's } \\
\text { symptoms that affect the patients' ability to cope with } \\
\text { daily activities }\end{array}$ & $10(12)$ & 43(49) & 33(37) & $10(11)$ & $1(1)$ & $3(4)$ & $35(23)$ & $65(43)$ \\
\hline $\begin{array}{l}\text { I teach TBI patients' family members how to assist } \\
\text { with eating when the patient suffers from problems } \\
\text { carrying out such activities }\end{array}$ & $16(18)$ & $37(42)$ & $39(45)$ & $4(5)$ & 1(1) & $3(3)$ & $45(29)$ & $55(36)$ \\
\hline $\begin{array}{l}\text { I teach TBI patients' family members in using aids } \\
\text { (e.g. walker, wheelchair) when the patient is suffering } \\
\text { from, e.g., memory loss }\end{array}$ & $12(14)$ & 31(35) & 35(39) & $19(21)$ & - & $3(4)$ & $67(43)$ & $33(21)$ \\
\hline $\begin{array}{l}\text { I teach TBI patients' family members how to assist the } \\
\text { patient in, e.g., dressing when the patient is suffering } \\
\text { from a lack of initiative }\end{array}$ & $8(9)$ & 33(38) & $40(45)$ & $15(18)$ & $2(2)$ & 2(2) & $55(36)$ & 45(29) \\
\hline $\begin{array}{l}\text { I provide guidance to TBI patient's family members } \\
\text { with respect to helping the patient with bathing when } \\
\text { the TBI patient suffers from poor concentration }\end{array}$ & $6(7)$ & $20(23)$ & $40(46)$ & 25(29) & $4(4)$ & $5(5)$ & $57(36)$ & $43(27)$ \\
\hline \multicolumn{9}{|c|}{ Supporting family members with respect to breaks and recreation } \\
\hline $\begin{array}{l}\text { I encourage TBI patients' family members to think about } \\
\text { themselves too }\end{array}$ & 16(18) & $53(61)$ & 23(26) & $5(6)$ & 2(2) & $1(1)$ & $86(57)$ & 14(9) \\
\hline $\begin{array}{l}\text { I offer TBI patients' family members the chance to have a } \\
\text { break (e.g. visit the cafeteria or go outside) }\end{array}$ & $7(8)$ & 28(32) & $35(40)$ & $21(24)$ & $5(5)$ & $4(5)$ & $82(50)$ & $18(11)$ \\
\hline $\begin{array}{l}\text { I tell TBI patients' family members about the } \\
\text { opportunities to eat at the hospital }\end{array}$ & $10(12)$ & 25(28) & 33(38) & $26(30)$ & $2(2)$ & $4(4)$ & $90(49)$ & $10(6)$ \\
\hline $\begin{array}{l}\text { I help TBI patients' family members with sleeping } \\
\text { arrangements }\end{array}$ & $4(4)$ & 26(30) & $37(42)$ & $26(30)$ & $4(4)$ & $3(4)$ & $83(52)$ & $17(11)$ \\
\hline $\begin{array}{l}\text { I arrange for TBI patients' family members to have the } \\
\text { opportunity to rest }\end{array}$ & $4(4)$ & $12(14)$ & $30(34)$ & $36(41)$ & $9(11)$ & $9(10)$ & $77(44)$ & $23(13)$ \\
\hline
\end{tabular}


Table 2. (Continued)

\begin{tabular}{|c|c|c|c|c|c|c|c|c|}
\hline \multirow[b]{2}{*}{ Items focusing on practical support } & \multicolumn{8}{|c|}{ Nursing staff's evaluations about providing practical support \% (n) } \\
\hline & $\begin{array}{l}\text { Always } \\
\%(n)\end{array}$ & $\begin{array}{l}\text { Often } \\
\%(n)\end{array}$ & $\begin{array}{l}\text { Occasio- } \\
\text { nally } \\
\%(n)\end{array}$ & $\begin{array}{l}\text { Seldom } \\
\%(n)\end{array}$ & $\begin{array}{l}\text { Never } \\
\%(n)\end{array}$ & $\begin{array}{l}\text { Does not } \\
\text { affect } \\
\text { me \%(n) }\end{array}$ & Basic & Advanced \\
\hline \multicolumn{9}{|c|}{$\begin{array}{l}\text { Teaching family members in dealing with the TBI patient's mood swings and } \\
\text { the symptoms caused by the TBI }\end{array}$} \\
\hline $\begin{array}{l}\text { I teach TBI patients' family members that being present } \\
\text { may alleviate restlessness }\end{array}$ & $9(11)$ & $53(61)$ & $30(34)$ & $6(7)$ & $1(1)$ & $1(1)$ & $68(44)$ & $32(21)$ \\
\hline $\begin{array}{l}\text { I teach TBI patients’ family members that maintaining a } \\
\text { calm environment alleviates restlessness }\end{array}$ & $5(6)$ & $31(35)$ & $41(47)$ & $17(19)$ & $4(5)$ & 2(2) & $57(37)$ & $43(27)$ \\
\hline $\begin{array}{l}\text { I teach TBI patients' family members that the brain injury } \\
\text { may cause sleep disturbances }\end{array}$ & $2(2)$ & $37(42)$ & $35(40)$ & $23(26)$ & 2(3) & $1(1)$ & $51(32)$ & $49(31)$ \\
\hline $\begin{array}{l}\text { I teach family members that I consider the TBI patients' } \\
\text { unique situation when planning their care }\end{array}$ & $7(8)$ & $23(27)$ & $38(43)$ & $21(24)$ & $9(10)$ & 2(2) & $64(41)$ & $36(23)$ \\
\hline $\begin{array}{l}\text { I teach family members to call an aggressive TBI patient } \\
\text { by name }\end{array}$ & 3(3) & 21(24) & 34(39) & $24(28)$ & $15(17)$ & $3(3)$ & $48(30)$ & $52(33)$ \\
\hline $\begin{array}{l}\text { I teach TBI patients' family members how to alleviate the } \\
\text { patient's symptoms, such as muscular spasticity }\end{array}$ & $4(4)$ & 16(18) & $41(47)$ & $35(40)$ & $3(4)$ & $1(1)$ & $40(26)$ & 60(39) \\
\hline $\begin{array}{l}\text { I teach family members how to anticipate a TBI patient's } \\
\text { aggressive behavior when the patient suffers from mood } \\
\text { swings }\end{array}$ & 2(2) & $16(18)$ & $38(44)$ & 30(34) & 11(12) & $3(4)$ & $32(20)$ & $68(43)$ \\
\hline $\begin{array}{l}\text { I teach TBI patients' family members how to try to } \\
\text { prevent aggressive behavior when the TBI causes the } \\
\text { patient to have a short temper }\end{array}$ & 1(1) & $15(17)$ & $40(46)$ & $31(35)$ & $10(11)$ & $3(4)$ & $34(21)$ & $66(41)$ \\
\hline
\end{tabular}

When examining the evaluations of the Finnish nurses on the basis of the nursing intervention sum variables, i.e. how often they provide practical support to TBI patients' family members; we found that liaison with family members, planning the TBI patient's discharge from hospital and teaching in daily activities were carried out most often. However, the nurses generally stated that they occasionally supported family members' with respect to breaks and recreation, and taught family members how to deal with TBI patient’s mood swings and the symptoms caused by the TBI (see Table 4).

When investigating the relationships between the background characteristics and nursing intervention sum variables, the following statistically significant differences were observed. Practical nurses stated that they carried out nursing interventions related to liaison with TBI patients' family members less frequently than the registered nurses. In addition, the length of work experience was related to the frequencies that the nursing staff taught family members to deal with a TBI patient's mood swings and offered family members opportunities for breaks or recreation (see Table 3).

Table 3. Background variables and their relationships to the mean nursing intervention sum variables linked to practical support

\begin{tabular}{|c|c|c|c|c|c|c|c|c|c|c|}
\hline \multirow[b]{2}{*}{ Background characteristics } & \multicolumn{2}{|l|}{ F1 } & \multicolumn{2}{|l|}{ F2 } & \multicolumn{2}{|l|}{$\overline{F 3}$} & \multicolumn{2}{|l|}{ F4 } & \multicolumn{2}{|l|}{ F5 } \\
\hline & Mean & SD & Mean & SD & Mean & SD & $\begin{array}{l}\text { Mea } \\
\text { n }\end{array}$ & SD & Mean & SD \\
\hline \multicolumn{11}{|l|}{ Age group (years) } \\
\hline Under 35 & 3.5 & 0.665 & 2.8 & 0.686 & 3.2 & 0.702 & 3.7 & 0.662 & 4.3 & 0.548 \\
\hline $36-45$ & 3.4 & 0.715 & 2.9 & 0.743 & 3.1 & 0.750 & 3.6 & 0.824 & 4.0 & 0.563 \\
\hline 46 or more & 3.6 & 0.655 & 3.1 & 0.643 & 3.4 & 0.725 & 3.6 & 0.770 & 4.2 & 0.699 \\
\hline Education & & & & & & & & & \multicolumn{2}{|c|}{$p=0.021$} \\
\hline Practical nurse & 3.6 & 0.641 & 2.9 & 0.621 & 2.9 & 0.837 & 3.6 & 0.863 & 3.8 & 0.787 \\
\hline RN (educated at a college of nursing) & 3.5 & 0.677 & 3.0 & 0.673 & 3.3 & 0.697 & 3.6 & 0.776 & 4.2 & 0.545 \\
\hline $\begin{array}{l}\text { RN (educated at a university of applied } \\
\text { sciences) }\end{array}$ & 3.4 & 0.693 & 3.0 & 0.754 & 3.2 & 0.704 & 3.7 & 0.671 & 4.2 & 0.672 \\
\hline
\end{tabular}


Table 3. (continued)

\begin{tabular}{|c|c|c|c|c|c|c|c|c|c|c|}
\hline \multirow{2}{*}{ Background characteristics } & \multicolumn{2}{|l|}{ F1 } & \multicolumn{2}{|l|}{ F2 } & \multicolumn{2}{|l|}{ F3 } & \multicolumn{2}{|l|}{ F4 } & \multicolumn{2}{|l|}{ F5 } \\
\hline & Mean & SD & Mean & SD & Mean & SD & Mean & SD & Mean & SD \\
\hline $\begin{array}{l}\text { Work experience as a nursing staff } \\
\text { member (years) }\end{array}$ & & & $\mathrm{p}=0.036$ & & $\mathrm{p}=0.015$ & & & & & \\
\hline Less than 3 & 3.2 & 0.863 & 2.5 & 0.831 & 2.8 & 0.597 & 3.6 & 0.680 & 4.2 & 0.621 \\
\hline 3- 10 & 3.5 & 0.614 & 3.0 & 0.685 & 3.1 & 0.837 & 3.6 & 0.667 & 4.1 & 0.679 \\
\hline $11-20$ & 3.5 & 0.692 & 2.9 & 0.677 & 3.3 & 0.608 & 3.7 & 0.870 & 4.1 & 0.588 \\
\hline 21 or more & 3.7 & 0.661 & 3.2 & 0.652 & 3.5 & 0.735 & 3.8 & 0.747 & 4.3 & 0.597 \\
\hline $\begin{array}{l}\text { Work experience in current work unit } \\
\text { (years) }\end{array}$ & & & & & $\mathrm{p}=0.059$ & & & & & \\
\hline Less than 3 & 3.5 & 0.800 & 2.8 & 0.822 & 3.0 & 0.631 & 3.7 & 0.841 & 4.2 & 0.634 \\
\hline 3- 10 & 3.4 & 0.592 & 2.9 & 0.654 & 3.3 & 0.810 & 3.6 & 0.690 & 4.1 & 0.648 \\
\hline $11-20$ & 3.6 & 0.707 & 3.2 & 0.596 & 3.3 & 0.654 & 3.7 & 0.713 & 4.1 & 0.469 \\
\hline 21 or more & 3.7 & 0.691 & 3.1 & 0.726 & 3.6 & 0.732 & 3.8 & 0.852 & 4.3 & 0.693 \\
\hline
\end{tabular}

Note. 5 = always, 4 = often, 3 = occasionally, 2 = seldom, 1 = never; F1 = Teaching family members in daily activities; F2 = Teaching family members in dealing with the TBI patient's mood swings and the symptoms caused by the TBI; F3 = Supporting family members with respect to breaks and recreation; F4 = Planning the TBI patient's discharge from hospital; F5 = Liaison with family members

\subsection{Nursing staff's evaluations of the need for basic or advanced compe- tence in relation to practical support}

The competency sum variables related to practical support for TBI patients' family members indicated that F1c: Teaching family members in daily activities and F2c: Teaching family members in dealing with mood swings seemed to demand more advanced competence than F3c: Supporting of family members with respect to break and recreation, F4c: Planning the TBI patient's discharge from hospital and F5c: Liaison with family members (see Table 4).

Table 4. Mean nursing intervention/competence sum variables linked to practical support

\begin{tabular}{|c|c|c|c|c|c|c|}
\hline \multirow{2}{*}{ Item } & \multicolumn{3}{|c|}{ Intervention sum variables } & \multicolumn{3}{|c|}{ Competence sum variables } \\
\hline & mean & SD & $\alpha$ & mean & SD & $\alpha$ \\
\hline Liaison with family members & 4.2 & 0.617 & 0.61 & 1.2 & 0.367 & 0.92 \\
\hline Planning the TBI patient's discharge from hospital & 3.7 & 0.754 & 0.76 & 1.3 & 0.362 & 0.69 \\
\hline Teaching family members in daily activities & 3.5 & 0.685 & 0.92 & 1.2 & 0.379 & 0.92 \\
\hline $\begin{array}{l}\text { Supporting family members with respect to breaks and } \\
\text { recreation }\end{array}$ & 3.1 & 0.746 & 0.84 & 1.2 & 0.329 & 0.90 \\
\hline $\begin{array}{l}\text { Teaching family members in dealing with the TBI patient's } \\
\text { mood swings and the symptoms caused by the TBI }\end{array}$ & 3.0 & 0.705 & 0.90 & 1.5 & 0.376 & 0.89 \\
\hline
\end{tabular}

Note. $\mathrm{SD}=$ standard deviation; $\alpha$ = Crohnbach's alpha; Intervention sum variables ( 5 = always, 4 = often, 3 = occasionally, 2 = seldom, 1 = never $)$; Competence sum variables $(1$ = basic competence, 2 = advanced competence)

No statistically significant relationships were identified between the competence sum variables and the nursing intervention sum variables. When examining individual practical support variables by means of Oneway ANOVA, we found that the nurses considered those teaching TBI patients' family members about how to assist with bathing when the patient suffers, for example, from poor concentration required advanced competence. When asked about the frequency of the intervention, only a quarter of the nurses stated that they often taught family members about bathing in these circumstances. 


\section{Discussion}

\subsection{Examination of the results}

The results indicate that nursing staff provided practical support to the TBI patients' family members frequently, and considered providing practical support to require mostly a basic level of competence. However, the nursing intervention "Teaching family members in dealing with the TBI patient's mood swings and the symptoms caused by TBI" was carried out only occasionally and nurses considered that providing that kind of practical support needed advanced competence. One reason for this may be that nurses are unaware of TBI patients' personalities before their accidents. This is an issue that should be addressed, because previous studies have found that family members believe they receive insufficient support in relation to the patient's behavioral dysfunctions and mood swings ${ }^{[14-16]}$.

In addition, it seems that nurses do not always see in-home support as part of their primary role. However, nurses have a crucial role in multidisciplinary teams because they are closest to the TBI patients and their family members. Thus, for instance, TBI patients and their families could benefit from nurses giving more exact information to social workers about TBI patients' conditions and needs when planning discharge. Therefore, nurses should share their opinions about TBI patients' situations in multiprofessional teams with physicians, social workers and other professionals to improve the care of TBI patients and their family members. The results also showed that the current emphasis is more on patient-centered than on family-centered care, because only $37 \%$ of the respondent nurses often included family members in planning patients' return home from hospital. However, nurses can empower family members by encouraging them to participate in TBI patients' care ${ }^{[9]}$. Therefore, to assure continuity and quality of care, it's essential to invite TBI patients and family members to attend multiprofessional team meetings.

Liaison with family members was considered to require basic competence and was the activity carried out most often. Family members generally wish to participate in caring for the TBI patient, thus they are likely to wish to speak to the doctor ${ }^{[28]}$. Accordingly, nearly all the nursing staff reported that they arranged for family members to speak with the attending doctor. However, the practical nurses did this less frequently than the registered nurses, possibly because arranging meetings with the doctor is seen as the job of a registered nurse.

The nurses participating in this study also considered that planning the TBI patient's discharge from hospital and informing family members about support services required basic competence. However, only half of the nursing staff included family members in planning the patient's discharge, although more than half stated that they informed family members about support services (e.g. the availability of a physiotherapist, speech therapist or social worker). This is important, because family members need teaching about how to apply for various types of financial support they are entitled to in order to cope with reductions in family income resulting from the TBI ${ }^{[21]}$. In addition, family members frequently need the continuing support of professionals during the TBI patient's rehabilitation at home.

Regarding daily activities, most nurses stated that they taught family members how to support the independent functioning and self-care of the patient, e.g. eating independently. Having family members help with eating is probably seen as an easy way to include the family members in patient care. The nurses thought that such interventions require basic competence. However, they seldom told family members how to help a TBI patient suffering from poor concentration or initiative to bathe and dress. This is another issue that requires further attention or training, as family members need teaching to support the rehabilitation of a patient suffering from a lack of initiative later at home, and the wellbeing of family members reportedly increases when they feel they can manage as caregivers ${ }^{[21]}$.

The results also showed that nursing staff seldom offered families chances to take breaks or recreation, or help with sleeping arrangements, although supporting the TBI patients' family members in this respect was seen as requiring basic competence. Family members get stressed because they want to make sure the patient receives good care, and therefore ignore their own well-being ${ }^{[22]}$. Thus, it is important to ensure that family members get enough rest, especially in Finland, 
where treatment of severe brain injuries is concentrated in university hospitals that are often hundreds of kilometers from family members' homes.

Most of the responding nurses stated that they often taught family members that being present and maintaining a calm environment can alleviate restlessness, and more than half considered that these interventions required basic competence. However, they seldom taught family members how to anticipate and prevent a TBI patient's aggressive behavior and thought that these interventions required advanced competence. Because TBI patient's challenging behavior and aggressiveness cause stress for family members. This is a further issue that may require further training, as TBI patients' challenging behavior and aggressiveness cause stress for family members ${ }^{[20]}$.

\subsection{Ethics and reliability of the study}

Permits for the study were obtained from each of the five organizations involved according to the relevant ethical research principles and protocols. Participation of the nursing staff in the study was based on their informed consent. The cover letter accompanying the questionnaire informed the participants about the voluntary nature of their participation, the confidentiality of the responses and that they would remain anonymous. Information on how to contact the researcher and her supervisors were attached to each questionnaire so that the participants could communicate with them if they had any questions or comments regarding the study. The anonymity of the participants was ensured because the replies were returned without names, the data were handled with absolute confidentiality and the results will only be published in a way that prevents the identification of individual participants. The results of the study have been presented in an objective, open and honest manner ${ }^{[29]}$.

External validity was ensured by inviting all practical and registered nurses from the neurosurgical wards of all Finnish university hospitals to participate in the study ${ }^{[30]}$. The validity of the questionnaire content was verified by basing the statements therein on previous research and a literature review, plus evaluations from a team of experts. In addition, two nurses undertook pre-testing of the questionnaire. In their opinion the questionnaire did not lack anything essential, the statements were understandable and the questionnaire was easy to answer.

The reliability of the questionnaire was examined using explorative factor analysis and a solution involving five factors was selected. The internal consistency of the questionnaire was tested by calculating Cronbach's alpha coefficients ${ }^{\text {[31, 32] }}$. The values were sufficiently high, ranging from 0.61 to 0.92 . The reliability of the results was ensured by including in the study all Finnish university hospital neurosurgical wards that treat TBI patients. The sample can, therefore, be considered representative ${ }^{[30]}$.

\section{Limitations}

The generalizability of the results is weakened by the small sample size, although the response rate was good. The data collection was carried out partly in the summer vacation season, during which there may be pressure on staff time, which may have affected the participants' opportunity to complete the questionnaire. In the preliminary testing, the nurses considered that the questionnaire would take 30-60 minutes to complete. The findings may not be relevant to nurses caring for veterans with TBI because participants in this study had no experience of combat-related TBI patients and their family members. Thus, the applicability of the results to such TBI patients is not known.

\section{Relevance to clinical practice}

The sub-categories identified by factor analysis representing the aspects of practical support for TBI patients' family members (teaching family members in daily activities, teaching family members to deal with mood swings and other symptoms caused by injury, supporting family members with respect to breaks and recreation, planning the patient's 
discharge from hospital and liaison with family members) could be utilized as a framework for orientation material. Thus, the orientation of new nurses would include all skills required for providing practical support to TBI patients' family members.

The results of the study show that providing practical support to TBI patients' family members requires nursing staff to possess extensive and multidimensional competences related to the effects of the symptoms caused by the TBI on the patient's ability to function (e.g. lack of initiative, poor concentration, not being aware of their own symptoms, impulsiveness and memory dysfunctions). Challenges for follow-up studies include addressing both nursing staff's competence and the needs of TBI patients and their family members with respect to practical support on neurosurgical wards. In addition, it is important to conduct follow-up studies including nurses caring for veterans with TBI in other countries. Our findings about the Finnish neurosurgical nurses' perceptions of supporting TBI patients' family members could be utilized in other countries by nurse managers, nurses and nurse educators to improve care and in-service education.

\section{Acknowledgement}

This study was supported by grants from The Finnish Nurses Educational Association and the Department of Nursing Science, University of Eastern Finland. We are grateful to all nurses who participated in the study. We also thank Statistician, MSc Hannu Isoaho for assistance with the statistical analysis.

\section{References}

[1] Koskinen S, Alaranta H. Traumatic brain injury in Finland 1991-2005: A nationwide register study of hospitalized and fatal TBI. Brain Injury. 2008; 22: 205-214. PMid:18297592 http://dx.doi.org/10.1080/02699050801938975

[2] Öhman J, Alaranta H, Kaipio M-L, Malmivaara A, Nybo T, Ojala M, Randell T, Salonen O, Turkka J, Vataja, Ylinen AR. Aivovammat. Käypähoito -suositus. Suomalainen lääkäriseura. (In English: Brain injuries. Current Care recommendation. The Finnish Medical Society.) 2008. Available from: http://www.kaypahoito.fi/web/kh/suositukset/ March 2011.

[3] Clinical Practice Guideline. Management of Concussion/mild Traumatic Brain Injury. The Management of concussion /mTBI Working Group. 2009. Available from: http://www.guideline.gov/content.aspx?id=15677

[4] Thompson HJ, Mcilvoy L, Meyer K. Nursing Management of Adults with severe Traumatic Brain Injury. AANN Clinical Practice Guideline Series. Available from: http://www.guideline.gov/content.aspx?id=13576\&search. 2009, April 2011.

[5] DVBIC. Defense and Veterans’ Brain Injury Center (DVBIC). 2012. Blast injuries. Retrieved August 16, 2012. Available from: http://www.dvbic.org/TBI---The-Military/Blast-Injuries.aspx.

[6] Finfgeld-Connett D. Clarification of social support. Journal of Nursing Scholarship. 2005; 37: 4-9. PMid:15813580

[7] Coco K, Tossavainen K, Jääskeläinen JE, Turunen H. Support for Traumatic brain injury patients' family members in neurosurgical nursing: A systematic review. Journal of Neuroscience Nursing. 2011; 43: 337-348. PMid:22089411 http://dx.doi.org/10.1097/JNN.0b013e318234ea0b

[8] Nelms T, Eggenberger S. The essence of the family critical experience and nurse-family meetings. Journal of Family Nursing. 2012; 16:462-489. PMid:21051759 http://dx.doi.org/10.1177/1074840710386608

[9] Zarubi KL, Reiley P, McCarter B. Putting patients and families at the center of care. Journal of Nursing Administration. 2008; 38:275-281. PMid:18562831 http://dx.doi.org/10.1097/01.NNA.0000312789.95717.81

[10] Sinnakaruppan I, Downey B,Morrison S. Head injury and family carers: a pilot study to investigate an innovative communitybased educational programme for family carers and patients. Brain Injury. 2005; 19: 283-308. PMid:15832874 http://dx.doi.org/10.1080/02699050400003924

[11] Rodgers ML, Strode AD, Norell DM, Short RA, Dyck DG, Becker B. Adapting multiple-family group treatment for brain and spinal cord injury intervention development and preliminary outcomes. American Journal of Physical Medicine and Rehabilitation. 2007; 86:482-491. PMid:17515688 http://dx.doi.org/10.1097/PHM.0b013e31805c00a1

[12] Kreuzer J, Stejskal TM Ketchum JM, Marwitz JH, Taylor LA, Menzel JC. A preliminary investigation of the brain injury family intervention: Impact on family members. Brain Injury. 2009; 23:535-547. PMid:19484627 http://dx.doi.org/10.1080/02699050902926291

[13] Wongvatunyu S, Porter E. Mothers' experience of helping young adults with Traumatic Brain Injury. Journal of Nursing Scholarship. 2005; 37:48-56. http://dx.doi.org/10.1111/j.1547-5069.2005.00015.x 
[14] Lefebvre H, Levert MJ, Pelchat D, Lepage JG. Nature, sources, and impact of information on the adjustment of family caregivers: a pilot project. Canadian Journal of Nursing Research. 2008; 40:143-160. PMid:18459277

[15] Murray HM, Maslany GW, Jeffery B. Assessment of family needs following acquired brain injury in Saskatchewan. Brain Injury. 2006; 20: 575-585. PMid:16754283 http://dx.doi.org/10.1080/02699050600664590

[16] Winstanley J, Simpson G, Tate R, Myles B. Early indicators and contributors to psychological distress in relatives during rehabilitation following severe traumatic brain injury: findings from the brain injury outcomes study. Journal of Head Trauma Rehabilitation. 2006; 21: 453-466. PMid:17122677 http://dx.doi.org/10.1097/00001199-200611000-00001

[17] Lane-Brown A, Tate R. Interventions for apathy after traumatic brain injury. 2009. Cochrane Database of Systematic Reviews, Issue 2.

[18] Chronister J, Chan F, Sasson-Gelman J, Chung-Yi C. The association of stress-coping variables to quality of life among caregivers of individuals with traumatic brain injury. Neurorehabilitation. 2012; 27:49-62.

[19] Leith KH, Phillips L, Sample PL. Exploring the service needs and experiences of persons with TBI and their families: the South Carolina experience. Brain Injury. 2004; 18: 1191-1208. PMid:15666564 http://dx.doi.org/10.1080/02699050410001719943

[20] Chan J. Carers' perspective on respite for persons with acquired brain injury. International Journal of Rehabilitation Research. 2007; 30: 137-146. PMid:17473625 http://dx.doi.org/10.1097/MRR.0b013e32813a2f11

[21] Wells R, Dywan J,Dumas J. Life satisfaction and distress in family caregivers related to specific behavioral changes after traumatic brain injury. Brain Injury. 2005; 19: 1105-1115. PMid:16286324 http://dx.doi.org/10.1080/02699050500150062

[22] McCabe P, Lippert C, Weiser M, Hilditch M, Hartridge C, Villamere J. Community reintegration following acquired brain injury. Brain Injury. 2007; 21: 231-257. PMid:17364533 http://dx.doi.org/10.1080/02699050701201631

[23] Kneafsey R, Gawthorpe D. Head injury: long-term consequences for patients and families and implications for nurses. Journal of Clinical Nursing. 2004; 13: 601-608. PMid:15189413 http://dx.doi.org/10.1111/j.1365-2702.2004.00903.x

[24] Verhaeghe S, Defloor T, Grypdonck M. Stress and coping among families of patients with traumatic brain injury: a review of literature. Journal of Clinical Nursing. 2005; 14: 1004-1012. PMid:16102152 http://dx.doi.org/10.1111/j.1365-2702.2005.01126.x

[25] Jumisko E, Lexell J,Soderberg S. Living with moderate or severe traumatic brain injury: The meaning of family members' experiences. Journal of Family Nursing. 2007; 13: 353-369. PMid:17641113 http://dx.doi.org/10.1177/1074840707303842

[26] Rotondi AJ, Sinkule J, Balzer K, Harris J, Moldovan R. A qualitative needs assessment of persons who have experienced traumatic brain injury and their primary family caregivers. Journal of Head Trauma Rehabilitation. 2007; 14-25. PMid:17235227 http://dx.doi.org/10.1097/00001199-200701000-00002

[27] Keenan A, Joseph L. The needs of family members of severe traumatic brain injured patients during critical and acute care: A qualitative study. Canadian Journal of Neuroscience Nursing. 2010; 32: 25-35. PMid:20865832

[28] Yetman L. Neuroscience nurses caring for family members of patients with acquired brain injury in acute ward settings: nursing defensively in a double bind. Canadian Journal of Neuroscience Nursing. 2008; 30: 26-33. PMid:19146205

[29] Burns N, Grove S. The practice of nursing research. Conduct, critique and utilizations. W.B. Saunders Company. Philadelphia. 2001.

[30] Polit DF, Beck CT. Nursing research. Generating and assessing evidence for nursing practice. 9th edn. Lippincott Williams \& Wilkins, Philadelphia. 2012.

[31] Heo S, Moser DK, Riegel B, Lynne AH, Christman N. Testing the psychometric properties of the Minnesota living with heart failure questionnaire. Nursing Research. 2005; 54: 260-272. http://dx.doi.org/10.1097/00006199-200507000-00009

[32] Bakas T, Champion V, Perkins SM, Farran CJ, Williams LS. Psychometric testing of revised 15-item Bakas Caregiving Outcomes Scale. Nursing Research. 2006; 55: 346-355. PMid:16980835 http://dx.doi.org/10.1097/00006199-200609000-00007 